\title{
EFEKTIVITAS PROGRAM BANTUAN PEMERINTAH BAGI USAHA MIKRO DI KABUPATEN PONOROGO
}

\author{
Nida Faizatul Mustofa ${ }^{1}$, Ratna Yunita ${ }^{2}$ \\ ${ }^{1,2}$ Institut Agama Islam Negeri Ponorogo, Indonesia \\ Email: nidafaiza608@gmail.com ${ }^{1}$, ratnayunita@iainponorogo.ac.id ${ }^{2}$
}

\begin{abstract}
One of the government's efforts to overcome the COVID-19 pandemic which has affected several sectors, one of which is the economic sector, is by launching the Government Assistance for Micro Enterprises (BPUM) program. This BPUM aims to support and maintain the sustainability of micro-enterprises as well as a form of saving the national economy during the COVID-19 pandemic that threatens the national economy. This program was only issued during the 2019 covid pandemic, so it is still very new and there is still not much research on this program. The problem in this research is how the effectiveness of achieving the objectives, integration, and adaptation of the Government Assistance for Micro Enterprises (BPUM) program is. This research program uses a field method using a qualitative approach and uses a descriptive type of research. The results of the research are, firstly, the measure of achieving the goals has not been effective because the targets have not been fully accurate and the management of aid funds is still not in accordance with the objectives. Second, the integration measure has not been effective because there is no socialization from related parties to the prospective recipients of the BPUM program. And third, the adaptation measure has not been effective either because the implementing party did not conduct monitoring before or after receiving this assistance program.
\end{abstract}

Keywords: Effectiveness, BPUM, Covid-19

\begin{abstract}
Abstrak: Salah satu upaya pemerintah dalam mengatasi pendemi covid-19 yang mengakibatkan beberapa sektor terdampak, salah satunya sektor perekonomian yaitu dengan mencanangkan program Bantuan Pemerintah bagi Usaha Mikro (BPUM). BPUM ini bertujuan untuk mendukung dan menjaga keberlangsungan usaha mikro serta sebagai bentuk penyelamatan ekonomi Nasional pada masa pandemi covid-19 yang mengancam perekonomian Nasional. Program ini baru dikeluarkan pada saat pandemi covid tahun 2019, sehingga masih sangat baru dan masih belum banyak penelitan tentang program ini. Permasalahan dalam penelitian ini adalah bagaimana efektivitas pencapaian tujuan, integrasi, dan adaptasi program Bantuan Pemerintah bagi Usaha Mikro (BPUM). Program Penelitian ini menggunakan metode lapangan dengan menggunakan pendekatan kualitatif dan menggunakan jenis penelitian deskriptif. Hasil penelitian yaitu, pertama pada ukuran pencapaian tujuan belum efektif dikarenakan target sasaran belum sepenuhnya tepat serta pengelolaan dana bantuan yang masih belum sesuai dengan tujuan. Kedua, pada ukuran integrasi belum efektif karena tidak adanya sosialisasi dari pihak terkait terhadap calon penerima program BPUM. Dan ketiga, pada ukuran adaptasi juga belum efektif karena pihak pelaksana tidak melakukan pemantauan sebelum maupun sesudah menerima program bantuan ini.
\end{abstract}

Kata kunci: Efektivitas, BPUM, Covid-19. 


\section{PENDAHULUAN}

Adanya pandemi covid-19 ini pemerintah berupaya untuk mengatasi hal yang sedang membahayakan perekonomian Nasional. Yang mana pemerintah mencanangkan program bantuan untuk pelaku usaha mikro dengan tujuan pemerintah adalah untuk menjaga dan membantu keberlangsungan hidup usaha mikro dalam mengahadapi tekanan akibat pandemi ini dan sebagai bentuk penyelamatan ekonomi Nasional (Peraturan Menteri Koperasi, Usaha Mikro, Dan Menengah Republik Indonesia Nomor 6 Tahun 2020, 2020).

Dengan demikian, seluruh Negara di dunia bahkan tidak sanggup dalam mengatasi pandemi ini, namun pemerintah terus berupaya untuk mengatasi berbagai dampaknya. Salah satu dampak yang ditimbulkan yaitu pada sektor ekonomi. Yang mana berdampak besar bagi sektor usaha yang menyebabkan terjadinya pemutusan hubungan kerja, menurunnya penyerapan tenaga kerja, penurunan pendapatan, bahkan menyebabkan banyak usaha yang bangkrut. Beberapa upaya yang dilakukan pemerintah dalam upaya penstabilan ekonomi yaitu dengan mencanangkan program Bantuan Pemerintah bagi pelaku Usaha Mikro (selanjudnya ditulis BPUM) atau Banpres Produktif(Peraturan Menteri Koperasi, Usaha Mikro, Dan Menengah Republik Indonesia Nomor 6 Tahun 2020, 2020).

Program bantuan pemerintah bagi usaha mikro (BPUM) merupakan bantuan pemerintah dalam bentuk uang yang diberikan kepada pelaku usaha mikro yang bersumber dari Anggaran Pendapatan dan Belanja Negara. BPUM ini diberikan untuk menjalankan usaha di tengah krisis ekonomi Indonesia akibat pandemi covid-19 dalam rangka mendukung pemulihan ekonomi Nasional dalam menghadapi ancaman yang membahayakan perekonomian Nasional serta sebagai bentuk penyelamatan ekonomi. Program BPUM ini diberikan satu kali dalam bentuk uang sejumlah Rp. 2.400.000 pada tahun 2020 dan Rp. 1.200.000 pada tahun 2021(Peraturan Menteri Koperasi, Usaha Mikro, Dan Menengah Republik Indonesia Nomor 6 Tahun 2020, 2020). Adapun jenis program bantuan Pemerintah pada masa pandemi covid-19 ini antara lain ialah Program Keluarga Harapan (PKH), Kartu Sembako, Program Bantuan Sosial Tunai (BST), subsidi listrik, subsidi kuota internet, Program Pra-Kerja, Program Bantuan Langsung Tunai dana Desa (BLT-DD). Perbedaan program BPUM dengan Program bantuan lain diatas yaitu program ini hanya untuk pelaku usaha mikro saja, khususnya yang terdampak pandemi covid-19. Dengan adanya program bantuan ini, menuai banyak 
problematika seperti tidak tepatnya sasaran pemerintah dimana bantuan ini untuk pelaku usaha mikro akan tetapi pada kenyataannya masih banyak masyarakat yang memperoleh bantuan ini tetapi tidak mempunyai usaha. Tidak sedikit juga masyarakat yang benarbenar mempunyai usaha tetapi tidak mendapatkan. Kemudian pelaku usaha yang mendapat program bantuan ini tidak benar-benar membelanjakan untuk menjalankan usahanya, akan tetapi masih menggunakannya untuk kebutuhan sehari-hari. Kedua, tidak adanya sosialisasi dari pihak kementerian Koperasi kepada calon penerima bantuan ini, sehingga masyarakat tidak terlalu memahami dan mengerti terkait program bantuan ini. Dimana, dengan adanya sosialisasi tersebut sangat penting mengingat supaya masyarakat mengetahui serta mengerti secara keseluruhan tujuan pemerintah dalam mencanangkan program bantuan. Ketiga, tidak adanya pemantauan dari pihak terkait setelah menerima program bantuan ini. Sedangkan, kemampuan adaptasi dari pihak Kementerian Koperasi sangat berperan agar tujuan pemerintah dapat tercapai secara maksimal. Dan perlu adanya adaptasi agar pihak terkait mampu menerjemahan perubahan-perubahan baik dari sisi intern maupun ekstern supaya dapat terus mengevaluasi program bantuan.

Dari fenomena yang terjadi menuai banyak pertanyaan apakah program bantuan ini sudah efektif pelaksanaannya atau masih perlu adanya evaluasi program. Efektif atau tidaknya program bantuan ini dapat diketahui dari sebuah pengukuran efektivitas. Pengukuran dalam arti tercapainya sasaran atau tujuan yang telah ditentukan sebelumnya.

\section{TINJAUAN LITERATUR}

\section{Efektivitas}

Efektivitas merupakan tingkat keberhasilan dalam pencapaian tujuan atau sasaran yang telah ditetapkan sebelumnya. Efektivitas juga merupakan suatu konsep yang lebih luas yang mana mencakup berbagai faktor di dalam maupun di luar diri seorang. Dengan demikian efektivitas tidak hanya dilihat dari sisi produktivitas saja, tetapi juga dapat dilihat dari sisi persepsi maupun sikap individu. Dalam hal ini, efektivitas adalah pencapaian tujuan atau sasaran dari organisasi dengan memanfaatkan sumber daya yang dimiliki secara efisien yang dilihat melalui sisi masukan (input), proses, maupun keluaran (output). Hal ini yang dimaksud dengan sumber daya meliputi ketersediaan anggota, sarana dan prasarana serta metode dan model yang digunakan. 
Menurut Carpenter, mengemukakan prinsip umum menilai efektivitas sebagai berikut(Made, 1998):

1) Menilai efektivitas adalah berkaitan dengan problem tujuan dan alat memproses input untuk menjadi output. Tujuan atau output harus tepat dengan kriteria.

2) Sistem yang dibandingkan harus sama, kecuali alat pemrosesnya. Misalnya yang harus sama atau homogen adalah tingkat pendidikan, kemampuan anak, sosial ekonomi, dan sebagainya.

3) Mempertimbangkan semua output utama.

4) Korelasi diharapkan bersifat kausalitas. Yaitu korelasi antara cara memproses dengan output harus kausalitas.

Pengukuran efektivitas dapat dilakukan dengan melihat hasil kerja yang dicapai oleh suatu organisasi. Efektivitas dapat diukur melalui berhasil tidaknya suatu organisasi mencapai tujuannya. Apabila suatu organisasi berhasil mencapai tujuan, maka organisasi tersebut dapat dikatakan telah berjalan dengan efektif. Hal terpenting adalah efektivitas tidak menyatakan tentang berapa besar biaya yang dikeluarkan untuk mencapai tujuan tersebut. Efektivitas hanya melihat apakah proses program atau kegiatan tersebut telah mencapai tujuan yang telah ditetapkan. Menurut Duncan yang dikutip oleh Richard M. Steers mengatakan mengenai Ukuran efektivitas yaitu sebagai berikut(Steers, 1985):

1) Pencapaian tujuan

Pencapaian adalah keseluruhan upaya pencapaian tujuan harus dipandang sebagai suatu proses. Agar pencapaian tujuan akhir semakin terjamin, diperlukan pentahapan, baik dalam arti penatahapan pencapaian bagian-bagiannya maupun pentahapan dalam arti periodisasinya. Pencapaian tujuan terdiri dari beberapa faktor, yaitu: kurun waktu dan sasaran yang merupakan target konkrit.

2) Integrasi

Integrasi yaitu pengukuran terhadap tingkat kemampuan suatu organisasi untuk mengadakan sosialisasi, pengembangan konsensus dan komunikasi dengan berbagai macam organisasi lainnya. Integrasi menyangkut proses sosialiasi. Dan dari integrasi berkaitan dengan perkembangan yang merupakan suatu fase setelah kelangsungan hidup (survive) dalam jangka panjang. Dalam organisasi harus bisa memperluas kemampuannya, sehingga bisa berkembang dengan baik dan sekaligus akan dapat melewati fase kelangsungan hidupnya(Sutrisno, 2018). Oleh karena itu di dalam 
integrasi akan membawa proses perkembangan suatu individu ataupun organisasi yang akan memberikan efek didalam keberlangsungan hidupnya ataupun didalam organisasi tersebut.

3) Adaptasi

Adaptasi adalah kemampuan organisasi untuk menyesuaikan diri dengan lingkungannya. Untuk itu digunakan tolak ukur proses pengadaan dan pengisisan tenaga kerja atau Sumber Daya Manusia (SDM). Kemampuan adaptasi dalam sebuah organisasi merupakan sampai seberapa jauh organisasi mampu menerjemahkan perubahan-perubahan baik dari sisi intern dan ekstern yang ada, kemudian dari adanya perubahan tersebut akan ditanggapi oleh organisasi yang bersangkutan.

\section{Program Bantuan Pemerintah bagi Usaha Mikro (BPUM)}

Dalam rangka untuk membantu dan menjaga keberlangsungan usaha pelaku usaha mikro dalam menghadapi tekanan akibat Corona Virus Disease 2019 (Covid-19) dan sesuai dengan Pasal 20 ayat (1) huruf b Peraturan Pemerintah Nomor 43 Tahun 2020 tentang Perubahan atas Peraturan Pemerintah Nomor 23 Tahun 2020 tentang Pelaksanaan Program Pemulihan Ekonomi Nasional Dalam Rangka Mendukung Kebijakan Keuangan Negara untuk Penanganan Pandemi Corona Virus Disease 2019 (Covid-19) dan/atau Menghadapi Ancaman yang Membahayakan Perekonomian Nasional dan/atau Stabilitas Sistem Keuangan serta Penyelamatan Ekonomi Nasional, perlu memberikan bantuan pemerintah bagi pelaku usaha mikro. Program Pemulihan Ekonomi Nasional yang selanjutnya disebut Program PEN adalah rangkaian kegiatan untuk pemulihan perekonomian nasional yang merupakan bagian dari kebijakan keuangan negara yang dilaksanakan oleh pemerintah untuk mempercepat penanganan pandemi COVID-19 dan/atau menghadapi ancaman yang membahayakan perekonomian nasional dan/atau stabilitas sistem keuangan serta penyelamatan ekonomi nasional.

Program PEN tersebut ialah Bantuan Pemerintah bagi pelaku Usaha Mikro atau disebut dengan BPUM adalah bantuan pemerintah dalam bentuk uang yang diberikan kepada pelaku usaha mikro yang bersumber dari Anggaran Pendapatan dan Belanja Negara. BPUM ini diberikan guna menjalankan usaha di tengah krisis akibat pandemi covid-19 sebagai upaya mendukung pemulihan ekonomi nasional dalam rangka menghadapi ancaman yang membahayakan perekonomian nasional serta sebagai bentuk 
penyelamatan ekonomi Nasional. Program BPUM ini diberikan satu kali dalam bentuk uang sejumlah Rp. 2.400.000 pada tahun 2020 dan Rp. 1.200.000 pada tahun 2021. Dengan disalurkan langsung ke rekening penerima BPUM. Penerima BPUM bisa diakses di https://eform.bri.co.id/bpum atau dihubungi langsung dari pihak perbankan. Kemudian penerima BPUM diminta untuk datang ke bank penyalur guna pembuatan buku rekening. (Peraturan Menteri Koperasi, Usaha Mikro, Dan Menengah Republik Indonesia Nomor 6 Tahun 2020, 2020) Pelaku Usaha Mikro penerima BPUM harus memenuhi persyaratan sebagai berikut:

1) Warga negara Indonesia

2) Memiliki Nomor Induk Kependudukan

3) Memiliki Usaha Mikro yang dibuktikan dengan surat usulan calon penerima BPUM dari pengusul BPUM beserta lampiranya yang merupakan satu kesatuan

4) Pelaku usaha mikro tidak sedang menerima Kredit Usaha Rakyat (KUR)

5) Pelaku usaha mikro belum pernah menerima dana BPUM

6) Telah menerima dana BPUM tahun anggaran sebelumnya

7) Bukan Aparatur Sipil Negara, anggota Tentara Nasional Indonesia, anggota Kepolisian Negara Republik Indonesia, pegawai BUMN, atau pegawai BUMD.

Mekanisme pendaftaran program Bantuan Pemerintah bagi Usaha Mikro, sebagai berikut: (Peraturan Menteri Koperasi Dan Usaha Kecil Dan Menengah Republik Indonesia Nomor 2 tahun 2021, 2021)

Mendaftarkan diri ke kantor kelurahan/desa setempat dengan kriteria sebagai berikut:

a) Calon penerima adalah masyarakat yang berada di lingkup kelurahan/desa tersebut

b) Calon penerima harus memiliki usaha dengan dibuktikan surat Keterangan Usaha dari kelurahan/desa

c) Calon penerima harus melengkapi dokumen yang dilampirkan, yaitu:

(1) Fotocopy Kartu tanda penduduk (KTP)

(2) Fotocopy Kartu Keluarga (KK)

(3) Fotocopy Nomor Induk Berusaha (NIB) Atau Surat Keterangan Usaha (SKU) dari kelurahan/desa

(4) Nomor handphone yang dapat dihubungi 
1) Data yang telah masuk ke kelurahan/desa akan disampaikan lurah/kepala desa kepada pihak dinas Perdagkum

2) Data yang sudah diterima oleh dinas Perdagkum akan dilakukan perepakan dan pembersihan data calon penerima BPUM. Pembersihan data yang dimaksud yakni verifikasi identitas kependudukan calon penerima BPUM berupa memiliki identitas sama, ganda, atau duplikasi dengan calon penerima BPUM lainnya; dan/atau Nomor Induk Kependudukan (NIK) tidak sesuai format administrasi kependudukan serta pengecekan terhadap kelengkapan dokumen persyaratan

3) Dinas perdagkum menyampaikan hasil verifikasi kepada Kementerian cq. deputi penanggungjawab program BPUM

4) Kementerian cq. deputi penanggung jawab program BPUM melakukan validasi data usulan calon penerima BPUM tidak sedang menerima Kredit Usaha Rakyat (KUR) melalui Sistem Informasi Kredit Program (SIKP) dan Nomor Induk Kependudukan (NIK)

5) Kuasa Pengguna Anggaran (KPA) dapat menetapkan pelaku Usaha Mikro yang berhak menerima BPUM berdasarkan data penerima BPUM pada tahun anggaran sebelumnya setelah melalui mekanisme validasi data

6) Kemudian Kuasa Pengguna Anggaran (KPA) melakukan pencairan dana BPUM dengan cara memberikan langsung kepada penerima BPUM atau melalui Bank penyalur BPUM

7) Untuk yang melalui pihak bank penyalur, penerima akan mendapatkan telepon/sms untuk datang ke bank guna melakukan pencairan. Atau calon penerima mengakses https://eform.bri.co.id/bpum untuk mengetahui usahanya terdaftar atau tidak.

8) Apabila terdaftar, penerima datang ke bank tersebut dengan membawa fotocopy KTP dan membuktikan bahwa namanya terdaftar sebagai penerima BPUM untuk melakukan pencairan

\section{METODE PENELITIAN}

Penelitian ini merupakan penelitian lapangan (field research) di Kabupaten Ponorogo, dengan pendekatan kualitatif menggunakan jenis penelitian deskriptif. Penelitian ini bertujuan untuk menganalisis pelaksanaan program Bantuan Pemerintah bagi Usaha Mikro di Kabupaten Ponorogo guna mengetahui tingkat efektivitas program bantuan tersebut. Pengumpulan data ini menggunakan teknik wawancara kepada pihak 
yang bersangkutan yaitu pihak kelurahan/desa, Dinas Perdagangan Koperasi dan Usaha Mikro serta penerima program bantuan, teknik observasi dan dokumentasi. Pada penelitian ini peneliti menggunakan teknik snowball sampling(Sugiono, 2017) untuk menemukan informan karena dalam hal ini peneliti tidak memperoleh data penerima program BPUM, peneliti hanya menerima rekomendasi dari pihak Dinas serta peneliti meminta rekomendasi dari penerima bantuan.

\section{HASIL DAN PEMBAHASAN}

\section{Efektivitas Pencapaian Tujuan Program Bantuan Pemerintah bagi Usaha Mikro (BPUM) di Kabupaten Ponorogo}

Keseluruhan upaya pencapaian tujuan harus dipandang sebagai suatu proses. Agar pencapaian tujuan akhir apat tercapai secara maksimal, diperlukan pentahapan, baik dalam arti penatahapan pencapaian bagian-bagiannya maupun pentahapan dalam arti periodisasinya. Efektivitas berhubungan antara tujuan dan hasil yang dinyatakan, dan menunjukan derajat kesesuaian antara tujuan yang dinyatakan dengan hasil yang dicapai. Tercapainya tujuan tersebut telah ditetapkan dengan indikator yang menjadi tolak ukur merupakan gambaran seberapa besar efektivitas dari kebijakan tersebut.

Target dalam Program Bantuan Pemerintah bagi Usaha Mikro (BPUM) yaitu untuk pelaku usaha mikro untuk membantu dan menjalankan usaha di tengah krisis akibat pandemi covid-19 dalam rangka mendukung pemulihan ekonomi Nasional dalam rangka menghadapi ancaman yang membahayakan perekonomian Nasional serta penyelamatan ekonomi. Akan tetapi, ditemukan persepsi yang berbeda dalam pencapaian tujuan pada efektivitas program Bantuan Pemerintah bagi Usaha Mikro (BPUM) di Kabupaten Ponorogo ini.

Berdasarkan hasil wawancara dengan pihak penyalur dari Dinas Perdagkum tentang ketepatan sasaran program Bantuan Pemerintah bagi Usaha Mikro (BPUM) Ibu Citra, beliau mengatakan bahwa pengolahan data dilakukan oleh pusat, sedangkan pusat tidak sepenuhnya mengetahui keadaan dilapangan.

"Kita dari pihak dinas sebagai penyalur hanya merekap data saja, hanya sebagai pengusul saja. Apakah banyak masyarakat yang memanipulasi usahanya itu diluar tanggungjawab kami. Karena kami hanya menerima data dari pendaftar kemudian kami setorkan langsung ke pusat" (Citra, Wawaancara, 2021) 
Hal ini diperkuat dari hasil wawancara dengan Bapak Yoyok selaku pihak penyalur dari Dinas Perdagkum, yang mengatakan bahwa belum sepenuhnya tujuan pemerintah tercapai. Karena masih banyak pedagang dan pelaku usaha lainnya yang belum mendapatkan program bantuan ini.

"Menurut saya ya nduk, terkait apakah bantuan ini tepat sasaran atau tidak, masih belum. Karena apa, masih banyak pedagang, wirausaha yang belum menerima bantuan. Ada juga yang mereka sampek datang ke kantor lapor kalau tidak menerima sms dari bank, sedangkan tetangganya yang barengan daftar kemarin sudah dapet dan tetangganya itu malah yang nggak punya usaha. Dengan begitu kan kita tahu kalau bantuan ini masih belum tepat sasaran" (Yoyok, Wawaancara, 2021)

Berdasarkan hasil data yang diperoleh mengungkapkan bahwa beliau pelaku usaha yang mana tidak menggunakan dana bantuannya untuk keperluan usahanya melainkan untuk keperluan lainnya dan untuk kebutuhan sehari-hari. Seperti yang diungkapkan Mas Riki salah satu penerima BPUM, dalam kutipan di bawah ini, bahwa beliau tidak menggunakan bantuan ini untuk kebutuhan usahanya kerena masih ada keperluan yang lebih penting untuk dipenuhi serta usaha yang dijalaninya dinilai tidak terdampak covid19.

"Saya pelaku usaha mbak, usahanya warung kopi. Saya baru merintis usaha 2 tahun ini. Dengan adanya pandemi ini warung kopi saya malah laris mbak. Karena banyak anak-anak yang nggak sekolah itu ngopi dan wifi an di tempat saya. Dengan begitu pendapatan saya meningkat sehingga warung saya tidak terlalu membutuhkan dana lebih. Menurut saya tepat sasaran mbak, karena saya pelaku usaha yang berhak menerima bantuan ini. Tetapi dalam penggunaan dana bantuan ini, saya tidak menggunakan untuk menjalankan usaha saya, akan tetapi saya gunakan untuk keperluan saya kuliah mbak, beli laptop. Karena saya juga semester akhir seperti njenengan, dan saya sangat membutuhkan itu" (Riki, Wawaancara ,2021)

Hal ini diperkuat oleh wawancara dari Ibu Indarni sebagai penerima BPUM, mengatakan bahwa dana BPUM ini tidak sepenuhnya digunakan usaha melainkan juga digunakan untuk kebutuhan sehari-hari, yang mana dengan adanya pandemi covid ini pendapatan beliau menurun sehingga untuk kehidupan sehari-hari lebih diutamakan.

"Usaha yang saya jalani ini dibidang kuliner mbak, warung sate gule kambing. Dimana, adanya pandemi ini sangat berpengaruh terhadap pendapatan kita mbak. Kadang sehari Cuma dua pelanggan, pernah juga nggak ada pelanggan sama sekali mbak. Dengan adanya bantuan ini sangat membantu mbak sebenarnya untuk kebutuhan sehari-hari. Saya tidak menggunakan bantuan ini sepenuhnya untuk usaha mbak, mau gimana mbak, wong buat kebutuhan sehari-hari aja masih 
kurang. Sebagian juga tak buat keperluan usaha mbak. Tapi yo wis amrih mlakune kabeh mbak ngene iki” (Indarni, Wawancara, 2021)

Berdasarkan data yang diperoleh dalam penelitian ini menurut Ibu Lely mengungkapkan bahwa beliau menggunakan dana bantuan ini tidak sesuai dengan tujuan pemerintah tidak tanpa alasan melainkan faktor ekonomi dan kondisi pandemi ini yang membuatnya melakukan hal tersebut. Karena kebutuhan sehari-hari yang belum sepenuhnya terpenuhi.

"Saya seorang Ibu rumahtangga mbak, tapi saya juga nyambi nerima orderan dengan posting-posting di WhatsApp, untuk tambah-tambah belanja kebutuhan mbak. Selama pandemi ini suami saya dirumahkan dan untuk mencukupi kebutuhan sehari-hari ya hanya dengan posting-posting barang ini mbak. Nah, dengan adanya bantuan ini sangat membantu pemenuhan kebutuhan di keluarga saya mbak. Kalau untuk modal usaha tidak terlalu membutukan mbak. Soalnya kan saya nggak stok barang, kalau ada orderan baru ngambil barang gitu. Ngambil ku juga bisa bayar belakangan mbak, jadi kan nggak butuh modal sebenernya mbak. Jadi uange bantuan itu tak buat keperluanku sehari-hari" (Lely, Wawancara, 2021)

Berdasarkan hasil wawancara diatas dapat disimpulkan bahwa target sasaran pada penerima BPUM di Kabupaten Ponorogo kurang tepat sasaran, serta dalam penggunaan uang dari bantuan BPUM masih belum maksimal digunakan untuk membantu keberlangsungan hidup usaha mikro di era pandemi saat ini.

Dalam penelitian ini, berdasarkan teori ukuran efektivitas menurut Duncan yang dikutip oleh Richard M. Steers(Steers, 1985), pada indikator pencapaian tujuan bahwa target sasaran yang masih kurang tepat serta dalam penggunaan uang bantuan yang masih kurang maksimal digunakan untuk keberlangsungan hidup usahanya pada masa pandemi. Sehingga jika diukur dengan membandingkan antara rencana yang telah ditentukan dengan hasil nyata yang telah dilakukan tidak tepat sehingga menyebabkan tujuan pemerintah yang ditujukan untuk pelaku usaha mikro untuk keberlangsungan hidup usaha ditengah krisis pandemi tidak tercapai sesuai dengan yang diharapkan. maka hal ini dikatakan belum efektif.

\section{Efektivitas Integrasi Program Bantuan Pemerintah bagi Usaha Mikro (BPUM) di Kabupaten Ponorogo}

Integrasi merupakan pengukuran terhadap tingkat kemampuan suatu organisasi untuk mengadakan sosialisasi, pengembangan konsensus dan komunikasi dengan 
berbagai macam organisasi lainnya. Integrasi menyangkut proses sosialiasi. Sosialisasi program merupakan kemampuan penyelenggara program dalam melakukan sosialisasi program sehingga informasi mengenai mereka tersampaikan kepada masyarakat pada umumnya dan sasaran peserta program pada khususnya.

Sosialisai program dikatakan titik awal dalam menentukan keberhasilan program. Hal ini dilakukan untuk melihat bagaimana kemampuan penyelenggara terkait BPUM dalam melakukan sosialisasi tersebut, sehingga informasi tentang BPUM dapat tersampaikan kepada masyarakat penerima program. Berdasarkan data yang diperoleh bahwasannya, tidak adanya sosialisasi yang menyeluruh kepada masyarakat terkait program BPUM ini, karena dari Kementerian cq. deputi penanggung jawab program BPUM juga tidak ada sosialisasi hanya saja mengirimkan surat meliputi peraturan dan mekanisme pendaftaran hingga pencairan dana bantuan ini.

Bapak Yoyok selaku pihak penyalur BPUM, beliau mengatakan bahwa tidak adanya sosialisasi terkait program bantuan ini sebelum dilakukannya pendaftaran kepada pihak penyalur oleh pihak pusat. Pihak pusat hanya melayangkan surat kepada dinas untuk diumumkan kepada masyarakat luas. Dengan demikian pihak dinas juga hanya mengirimkan surat melalui kecamatan setempat untuk dikirimkan lagi ke kelurahan/desa. Dengan demikian tidak menutup kemungkinan masyarakat tidak faham betul mengenai bantuan tersebut.

"Kalau untuk terkait sosialisasi, dari pusat itu nggak ada sosialisasi nduk. Jadi dinas cuma dikasih surat tok. Kemudian pihak dinas hanya mengumumkan ke kelurahan/desa persyaratan siapa yang berhak mendapatkan, apa saja yang harus dilampirkan, dan jumlah dana yang akan diterima, bagaimana mekanisme saat pencairan juga disampaikan" (Yoyok, Wawancara, 2021)

Berdasarkan hasil yang diperoleh dalam penelitian ini narasumber mengatakan bahwa, mereka tidak mengetahui tentang sosialisasi terkait program bantuan ini, mereka mendaftarkan usahanya karena informasi dari teman maupun tetangganya. Hasil wawancara dengan beberapa penerima BPUM, mengatakan bahwa:

“.....iya mbak bener, nggak ada sosialisasi......" (Wiwid, wawancara, 2021)

“......nggak tau sih mbak ada apa tidak, soale aku bukan asli sini gek aku dapete info juga dari temenku......" (Riki, wawancara, 2021)

“.......nggak ada sosialisasi mbak......” (Nuri, wawancara, 2021)

Berdasarkan hasil wawancara diatas dapat disimpulkan bahwa integrasi terhadap efektivitas Program Bantuan Pemerintah bagi Usaha Mikro (BPUM) dilihat dari proses 
sosialisasinya dikatakan belum efektif. Karena pada program BPUM ini tidak terdapat adanya sosialisasi dari pihak terkait terhadap masyarakat calon penerima bantuan. Dimana adanya sosialisasi tersebut sangat penting, mengingat supaya masyarakat mengetahui sasaran pemerintah di kalangan mana, apa tujuan pemerintah mencanangkan bantuan ini, serta membuka kesadaran masyarakat agar tidak hanya ikutikutan saja tanpa tahu tujuan dan siapa yang berhak menerima.

Pada penelitian ini, berdasarkan teori ukuran efektivitas menurut Duncan yang dikutip oleh Richard M. Steers, pada indikator integrasi yaitu kemampuan Kementerian cq. deputi penanggungjawab program BPUM dalam melakukan sosialisasi program BPUM belum dilakukan, sehingga informasi program belum dapat tersampaikan kepada masyarakat secara menyeluruh. Sosialisasi program bantuan ini dikatakan belum efektif dan maksimal dikarenakan Kementerian Koperasi RI dan Dinas Perdagangan Koperasi dan Usaha Mikro Kabupaten Ponorogo tidak melakukan sosialisasi secara langsung kepada masyarakat yang berakibat masyarakat kurang faham mengenai maksud dari program BPUM ini.

\section{Efektivitas Adaptasi Program Bantuan Pemerintah bagi Usaha Mikro (BPUM) di Kabupaten Ponorogo}

Adaptasi merupakan kemampuan organisasi dalam penyesuaian diri dengan lingkungannya. Kemampuan adapatasi dalam sebuah organisasi merupakan sampai seberapa jauh organisasi mampu menerjemahkan perubahan-perubahan baik dari sisi intern dan ekstern yang ada, kemudian dari adanya perubahan tersebut akan ditanggapi oleh organisasi yang bersangkutan. Pada penelitian ini, peneliti ingin mengetahui bagaimana sumber daya manusia, dalam hal ini Kementerian cq. deputi penanggung jawab program BPUM dalam merealisasikan atau melaksanakan program. Peran aktif dari Kementerian cq. deputi penanggung jawab program BPUM merupakan adaptasi program BPUM agar tujuan dari program BPUM dapat tercapai secara maksimal.

Dalam penelitian ini diperoleh data bahwasannya adaptasi dari pihak penyelenggara program berupa survey terkait sebelum dan sesudah terlaksananya program belum dilakukan. Dengan demikian tujuan pemerintah masih belum tepat sasaran dan belum efektif. Dimana dijelaskan oleh bapak Yoyok dalam kutipan wawancara bahwasannya pihak penyelenggara program tidak mengadakan ataupun menghimbau dinas setempat untuk melakukan survey sebelum dan setelah penerimaan bantuan. Dengan demikian 
program bantuan ini dikatakan belum efektif dikarenakan masih banyak pelaku usaha yang belum mendapatkan bantuan sedangkan mereka sangat terdampak adanya pandemi ini. Berikut ulasan wawancara dengan Bapak Yoyok:

"Kalau terkait adanya survey sebelum dan setelah program terlaksana tidak ada nduk. Di peraturan maupun di surat yang saya terima tidak ada pelaksana survey sebelum dan setelah penerimaan program BPUM” (Yoyok, wawancara, 2021)

Sebagaimana diungkapkan oleh beberapa nasasumber sebagai penerima program BPUM , bahwa mereka tidak menerima pemantauan sebelum maupun setelah menerima bantuan ini. Mereka hanya menerima telepon dari pihak perbankan bahwa mereka telah menerima bantuan pemerintah ini. Dan setelah penerimaan bantuan tidak ada tindakan lain dari pihak penyelenggara. Menurut beberapa narasumber, adanya pemantauan sangat diperlukan untuk memastikan bahwa program ini benar-benar tersalurkan sesuai tujuan pemerintah. Berikut beberapa hasil wawancara, sebagaimana diungkapkan dibawah ini:

"Tidak ada pemantauan mbak sebelum maupun setelah penerimaan program BPUM ini. kalau menurutku sih harusnya ada ya mbak, dengan begitu kan bantuan ini bisa tepat sasaran. Untuk pelaku usaha saja, yang nggak punya usaha otomatis tidak akan menerima." (Wiwid, wawancara, 2021) “....gak ada survey mbak....." (Sunarsih, wawancara, 2021)

"Kalau survey tidak ada dek. Kemarin hanya dapet telepon dari bank kalau dapet bantuan. Untuk setelah mendapatkan juga ngga ada survey" (Tika, wawancara, 2021)

Berdasarkan data hasil wawancara di atas dapat diketahui bahwasannya tidak adanya proses adaptasi dari Kementerian cq. deputi penanggung jawab program BPUM dengan calon maupun penerima program BPUM. Karena peran aktif Kementerian cq. deputi penanggung jawab program BPUM dalam adaptasi program BPUM sangat penting agar tujuan dari program BPUM dapat tercapai secara maksimal. Sehingga dapat disimpulkan bahwa proses adaptasi program BPUM ini dikatakan belum efektif.

Dalam penelitian ini, berdasarkan teori ukuran efektivitas menurut Duncan yang dikutip oleh Richard M. Steers, pada indikator adaptasi program yaitu kegiatan pemantauan sebelum dan setelah terlaaksananya program BPUM ini sebagai bentuk perhatian pelaksana Kementerian cq. deputi penanggung jawab program BPUM kepada calon maupun penerima program. Adaptasi ini dinilai belum efektif dikarenakan pihak pelaksana belum melakukan pemantauan sebelum maupun sesudah menerima program bantuan. Sehingga tujuan pemerintah belum tercapai secara maksimal. 


\section{KESIMPULAN}

Berdasarkan hasil penelitian yang dilakukan oleh peneliti terkait dengan efektivitas pelaksanaan program Bantuan Pemerintah bagi Usaha Mikro (BPUM) di Kabupaten Ponorogo secara keseluruhan belum efektif dalam pelaksanaannya. Sesuai dengan indikator efektifitas menurut Duncan yang dikutip oleh Richard M. Steers, yaitu (1) indikator pencapaian tujuan yang belum efektif dikarenakan masih banyak pelaku usaha yang belum memperoleh bantuan ini serta pengelolaan uang bantuan yang belum digunakan sesuai tujuan, (2) indikator integrasi yang belum terlaksana dengan baik dikarenakan sosialisasi masyarakat dan penyampaian informasi tidak menyeluruh, serta (3) indikator adaptasi yang belum ada dari pelaksana Kementerian cq. deputi penanggung jawab program BPUM. Diharapkan kedepanya Kementerian Koperasi RI lebih mengoptimalkan programnya dari segala aspek demi tercapainya tujuan yang diharapkan.

\section{REFERENSI}

Made, P. (1998). Landasan Pendidikan. Jakarta: PT Rineka Cipta.

Peraturan Menteri Koperasi Dan Usaha Kecil Dan Menengah Republik Indonesia Nomor 2 tahun 2021. (2021). Peraturan Menteri Koperasi Dan Usaha Kecil Dan Menengah Republik Indonesia Nomor 2 Tahun 2021 Tentang Perubahan Atas Peraturan Menteri Koperasi Dan Usaha Kecil Dan Menengah Nomor 6 Tahun 2020 Tentang Pedoman Umum Penyaluran Bantuan Pemerintah Bagi Pelaku Usaha Mikro Untuk Mendukung Pemulihan Ekonomi Nasional Dalam Rangka Menghadapi Ancaman Yang Membahayakan Perekonomian Nasional Serta Penyelamatan Ekonomi Nasional Pada Masa Pandemi Corona Virus Disease 2019 (Covid-19).

Peraturan Menteri Koperasi, Usaha Mikro, Dan Menengah Republik Indonesia Nomor 6 Tahun 2020. (2020). Peraturan Menteri Koperasi, Usaha Mikro, Dan Menengah Republik Indonesia Nomor 6 Tahun 2020 Tentang Pedoman Umum Penyaluran Bantuan Pemerintah Bagi Pelaku Usaha Mikro Untuk Mendukung Pemulihan Ekonomi Nasional Dalam Rangka Menghadapi Ancaman Yang Membahayakan Perekonomian Nasional, Serta Penyelamatan Ekonomi Nasional Pada Masa Pandemi Corona Virus Disease 2019 (COVID-19).

Steers, R. M. (1985). Efektivitas Organisasi. Jakarta: PPM Erlangga.

Sugiono. (2017). Metode Penelitian Kuantitatif, Kualitatif, dan R\&D. Bandung: Alfa Beta.

Sutrisno, E. (2018). Budaya Organisasi. Jakarta: Prenadamedia Group. 